\title{
Depression in chronic heart failure
}

\author{
Rola depresji w niewydolności serca
}

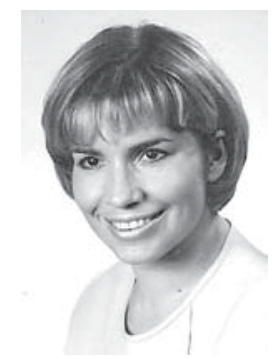

${ }^{1}$ III Katedra i Oddział Kliniczny Kardiologii Śląskiego Uniwersytetu Medycznego w Katowicach

${ }^{2}$ Katedra i Oddział Kliniczny Psychiatrii Śląskiego Uniwersytetu Medycznego w Katowicach

${ }^{3}$ Koło STN przy III Katedrze i Oddziale Klinicznym Kardiologii Śląskiego Uniwersytetu Medycznego w Katowicach

Kardiochirurgia i Torakochirurgia Polska 2012; 9 (4): 502-506

\begin{abstract}
Chronic heart failure (HF) is one of the most challenging problems in cardiology. Depression often coexists with HF. It can develop at any stage of heart disease: as a response to the diagnosis, disease exacerbation or poor prognosis. There is evidence of common pathophysiological pathways in the two diseases: neurohormonal stimulation, arrhythmias, inflammation and blood hypercoagulability. Although the correlation between depression and poor HF prognosis is well recognised, it is still uncertain whether depression treatment can have a positive effect on HF course. It should be noted that tricyclic antidepressants cause orthostatic hypotension, tachycardia and conduction disorders. Most studies confirm the safety of use of selective serotonin reuptake inhibitors (SSRI), bupropion and venlafaxine in $\mathrm{HF}$ patients. In conclusion, the detection of depressive symptoms and the efficacy of depression therapy in HF patients is unsatisfactory. This is largely due to the diagnostic difficulties arising from similar clinical manifestations and lack of guidelines in patients suffering from both diseases. Key words: depression, chronic heart failure.
\end{abstract}

\section{Background}

Despite dynamic advances in medicine, chronic heart failure (HF) still remains a significant medical, economic and social problem. The disease affects $2-3 \%$ of the general population but the incidence is on the rise, mainly due to improved cardiac care and longer survival time [1, 2]. Population studies show that $50-60 \%$ of patients with HF still die within 5 years of diagnosis [3, 4]. In HF, permanent cardiac dysfunction leads to a situation where cardiac output becomes lower than the tissue metabolic demand, or where correct cardiac output is main-

\section{Streszczenie}

Przewlekła niewydolność serca (HF) jest jednym z istotnych problemów współczesnej kardiologii. Schorzeniem, które często wspótistnieje z HF, jest depresja. Może ona wystąpić na każdym jej etapie jako odpowiedź na rozpoznanie choroby, zaostrzenie objawów lub informację o złym rokowaniu. Istnieją dowody na istnienie wspólnych dla tych dwóch chorób szlaków patofizjologicznych, takich jak pobudzenie neurohormonalne, zaburzenia rytmu, zapalenie i nadkrzepliwość krwi. Mimo udowodnionego związku depresji z niekorzystnym rokowaniem nie ustalono jednoznacznie, czy jej leczenie może wpływać korzystnie na przebieg HF. Należy pamiętać, że trójpierścieniowe leki przeciwdepresyjne powodują hipotonię ortostatyczną, tachykardię i zaburzenia przewodzenia bodźców. Większość przeprowadzonych dotychczas badań i obserwacji wykazała bezpieczeństwo stosowania selektywnych inhibitorów wychwytu serotoniny), bupropionu i wenlafaksyny u chorych z HF. W podsumowaniu należy podkreślić, że wykrywalność objawów depresyjnych i skuteczność leczenia depresji w grupie chorych z HF jest niezadowalająca. Wynika to przede wszystkim z trudności diagnostycznych związanych z podobnym obrazem klinicznym tych dwóch schorzeń.

Słowa kluczowe: depresja, przewlekła niewydolność serca.

tained at the expense of higher left ventricular filling pressure. When diagnosing HF, it is necessary to look for signs of the disease in the patients' medical history and physical examination; the presence of objective evidence of cardiac dysfunction, such as elevated natriuretic peptide levels or impaired cardiac function in echocardiographic examination, should also be verified [1]. Depression has a documented negative effect on the quality of life and prognosis in the HF population [5]. Regardless of whether it is a new episode, a chronic condition or remission, depression portends a more serious HF course and increased death risk $[5,6]$.

Address for correspondence: dr hab. n. med. Bożena Szyguła-Jurkiewicz, III Katedra i Oddział Kliniczny Kardiologii SUM, ul. Skłodowskiej-Curie 9, 41-800 Zabrze, tel. +48 604102 99, e-mail: centrala4@wp.pl 
Depression is a group of symptoms, the most prominent of which is mood lowering. At present, there are two systems of depression classification: the International Classification of Diseases and Related Health Problems (ICD-10), and the American Diagnostic and Statistical Manual of Mental Disorders (DSM-IV) [7, 8].

The diagnostic criteria for mild depressive episode according to ICD-10 are:

A. The general criteria for depressive episode (2-week duration) must be met.

B. At least two of the following three symptoms must be present:

1) depressed mood to a degree that is definitely abnormal for the individual, present for most of the day and almost every day, largely uninfluenced by circumstances, and sustained for at least 2 weeks;

2) loss of interest or pleasure in activities that are normally pleasurable;

3) decreased energy or increased fatiguability.

C. An additional symptom or symptoms from the following list should be present, to give a total of at least four:

1) loss of confidence and self-esteem;

2) unreasonable feelings of self-reproach or excessive and inappropriate guilt;

3) recurrent thoughts of death or suicide, or any suicidal behaviour;

4) complaints or evidence of diminished ability to think or concentrate, such as indecisiveness or vacillation;

5) change in psychomotor activity, with agitation or retardation (either subjective or objective);

6) sleep disturbance of any type;

7) change in appetite (decrease or increase) with corresponding weight change.

The DSM-IV criteria for major depressive episode are:

Five (or more) of the following symptoms have been present during the same 2-week period and represent a change from previous functioning; at least one of the symptoms is either: 1) depressed mood or 2) loss of interest or pleasure.

1) depressed mood most of the day, nearly every day;

2) markedly diminished interest or pleasure in all, or almost all, activities most of the day, nearly every day;

3) significant weight loss when not dieting or weight gain;

4) insomnia or hypersomnia nearly every day;

5) psychomotor agitation or retardation nearly every day;

6) fatigue or loss of energy nearly every day;

7) feelings of worthlessness or excessive or inappropriate guilt;

8) diminished ability to think or concentrate, or indecisiveness, nearly every day;

9) recurrent thoughts of death (not just fear of dying), recurrent suicidal ideation without a specific plan, or a suicide attempt or a specific plan for committing suicide.

Due to their clear universal criteria, both the DSM-IV and the ICD-10 classifications facilitate unequivocal diagnosis $[7,8]$.
The pathomechanism of depression is associated with dysfunction of the limbic system, the hypothalamus and the reticular system, caused by neurotransmission disorders mainly in the noradrenergic and serotonergic neurons (5-HT) [9]. Also dopaminergic, GABAergic and cholinergic neurons may participate in the pathogenesis of depression $[10,11]$. Depressive patients tend to have disorders of negative feedback in the hypothalamic-pituitary-adrenal axis. Somatotropin secretion is lower and disorders of the thyroid hormones and prolactin occur [9]. As result of depression-related neurohormonal and neuroimmunologic disorders, structural changes within the central nervous system take place [9]. In approximately half of depressive cases, the triggering factors are somatic or psychological. They may lead to hippocampal damage and decreased hippocampal volume [9]. The impact of so-called neuronal plasticity and remodelling is also considered in the pathophysiology of depression [12].

\section{Depression in chronic heart failure}

Rutledge's large-scale meta-analysis of studies on depression in HF showed that the two diseases coexist in $9 \%$ to $60 \%$ of cases [13]. Depression may occur at any stage of HF: as a response to disease diagnosis, imposed change of lifestyle, sudden exacerbation of symptoms or poor prognosis in connection with hospitalization, treatment process and convalescence. Depression can be induced by disease-related stress, absence of emotional support, social isolation, and poor living and housing conditions. There is evidence of common pathophysiological pathways of the two diseases: neurohormonal stimulation, arrhythmias, inflammation and blood hypercoagulability, which seems to confirm the significance of depression in HF patients [14]. The presence of depression is also associated with increased activity of the hypothalamic-pituitary-adrenal system, which in turn causes central activation of the sympathetic system [15]. Depressive patients show disorders of sympathetic-adrenal regulation responsible for catecholamine release. Hypersecretion of epinephrine and norepinephrine in the adrenal medulla leads to higher heart rate and blood pressure. Another effect of sympathetic activation is electrical instability favouring the occurrence of arrhythmias [16]. Like HF patients, depressive patients show elevated levels of circulating pro-inflammatory cytokines and lower levels of anti-inflammatory cytokines, as well as activation of the coagulation system [17]. The similarities in the pathophysiological changes in the course of both diseases suggest that depression may accelerate HF and cause its progression, whilst HF may cause the manifestation or exacerbation of depressive disorders in predisposed patients.

The association between depression and HF has been observed in many studies. The MIND-IT trial (The Myocardial Infarction and Depression - Intervention Trial) showed that depression occurred more frequently in patients with more advanced left ventricular dysfunction after myocardial infarction [18]. In a population of patients in the HFACTION trial, Gottlieb et al. observed that depression sever- 
ity had little connection with objective HF severity indices, such as maximum oxygen consumption and natriuretic peptide levels. There was, however, a statistically significant relationship between NYHA class or the distance covered in the six-minute walk test, the results of which depend on the patient's subjective evaluation, well-being and motivation for action. The authors concluded that depression affects first and foremost the patients' perception of their disease as well as their quality of life [19]. Faris et al. observed the independent prognostic importance of depression in four-year follow-up in HF patients. Depression was present in $21 \%$ of the analysed patients and was diagnosed with the ICD-10 criteria; antidepressants were used in over $70 \%$ of cases. [20]. In the COACH study, over $900 \mathrm{CHF}$ patients were followed up for 18 months. Depression diagnosed with the CES-D scale (Center for Epidemiologic Studies Depression Scale) was an unfavourable prognostic factor for adverse cardiac events. The incidence of depression on admission was 39\%, and antidepressant treatment was used in $11 \%$ of patients [21]. Van den Broek et al. evaluated the incidence and prognostic value of depression in 208 patients with HF of various etiology (in 62\% ischemic) over a period of 11 years. The incidence of depression in the analysed group was $36.1 \%$. The presence of depression was an independent risk factor for poor outcome: it increased 2-fold the risk of death for cardiovascular causes and 1.5-fold the risk of all-cause death [22]. In their retrospective analysis of 5,719 patients of the OPTIMIZE-HF trial, Albert et al. observed depression in $13.6 \%$ of patients. Depression was an independent factor for prolonged hospitalisation and all-cause death within three months of discharge [23].

Based on the analysis of patients with end-stage HF followed up for 18 months, Tousoulis et al. observed a significantly lower risk of death for cardiovascular reasons in patients without depression than in patients with diagnosed depression (HR 0.709) [24].

\section{Depression and inflammation}

In many studies, the presence of depression was associated with significantly higher levels of inflammatory markers [25-27]. Based on an analysis of 517 patients of the $\mathrm{COACH}$ trial, Johansson et al. observed a correlation between depression evaluated on the CES-D scale and inflammation (inflammatory markers: interleukin- 6 and C-reactive protein) [25]. During the in-hospital period, they observed statistically higher levels of the above-mentioned inflammatory markers in patients with depression and HF of various etiology than in patients without depression. After 18 months of follow-up, the authors did not observe a similar correlation between the baseline levels of inflammatory markers and depression [25].

Based on an analysis of patients with stable HF, Parissis et al. observed significantly higher levels of TNF- $\alpha$ and interleukin-10 in patients with coexisting depression than in patients without depression [26]. In a group of out-patients, Moorman et al. diagnosed depression with the DSM-IV cri- teria in $37 \%$, of whom $60 \%$ received antidepressants [27]. Patients with depression had significantly higher levels of circulating STNFr1 (TNF- $\alpha$ receptor-1). At the same time, the group treated with antidepressants tended to have higher STNFr1 concentrations. The authors concluded that antidepressants do not lower the level of cytokines in patients with HF. Of all the recognized inflammatory markers, hs-CRP is considered the most potent risk factor for adverse cardiac events. The effect of hs-CRP level on prognosis in HF patients has been widely analysed. The largest study is the Val-HeFT multi-centre, randomized clinical trial [28]. The population study of over 4,000 patients showed that higher hs-CRP values are associated with lower left ventricular ejection fraction, higher NYHA class, worse quality of life and a worse neurohormonal profile. The prognostic value of hs-CRP was independent of B-type natriuretic peptide (BNP) level and HF etiology.

The independent prognostic value of CRP was confirmed by the prospective study of Xue et al. encompassing 128 patients with CHF of ischemic and non-ischemic etiology. In the studied group, elevated hs-CRP caused an almost 4-fold increase in the risk of death or re-hospitalisation due to HF exacerbation, as compared with the control group without coexisting HF [29]. Lamblin et al. confirmed the prognostic value of hs-CRP for adverse cardiac events only in patients with HF of ischemic etiology [30]. Other authors found a strong correlation between hs-CRP levels and poor prognosis also in non-ischemic dilated cardiomyopathy [31, 32].

\section{Depression treatment in patients with chronic heart failure}

Although the association between depression and poor outcome is well documented, it is not clear whether the treatment of depression may affect the course of HF. Antidepressants are known to have numerous adverse effects, which may have a negative impact on the course of HF. Most studies have shown selective serotonin reuptake inhibitors (SSRI) to be safe in cardiovascular diseases. Even in long-term follow-up, the use of these drugs was associated with only a small percentage of adverse effects and drug interactions [33]. According to the results of the SADHART-CHF trial (Safety and Efficacy of Sertraline for Depression in Patients with CHF), sertraline (an SSRI drug) can be safely used in HF patients [34]. The CREATE study (Canadian Cardiac Randomized Evaluation of Antidepressant and Psychotherapy Efficacy) confirms the efficacy and safety of citalopram (SSRI) in the treatment of depression in patients with cardiovascular diseases [35]. Moreover, a subanalysis of the CREATE study showed that citalopram may have a positive effect on endothelial function and nitric oxide bioavailability [35]. SSRI drugs show a slight anticholinergic, antihistamine and noradrenergic action, and are platelet aggregation inhibitors. In cardiac patients, they cause no significant changes on the electrocardiogram, although they slow down the heart rate. As SSRI drugs diminish platelet aggregation, they may prolong bleeding time. As they inhibit cytochrome P450 isoenzymes, they 
may interact with some cardiac drugs [36]. For this reason, they may increase blood concentrations of drugs metabolised by the cytochrome P450 system. Furthermore, SSRI bind with plasma proteins and displace other drugs, which increases their biological activity. Bupropion, a selective dopamine and noradrenaline reuptake inhibitor, is relatively safe for cardiac patients. It causes lesser hypotension than tricyclic drugs, does not affect myocardial conduction and contractility, and may be safely used in cardiac patients. It does not intensify ventricular arrhythmias or conduction blocks. As it is an inhibitor of cytochrome P450 isoenzymes, it may weaken the activity of beta blockers and class $1 C$ antiarrhythmic drugs [36].

Another drug worth considering in this difficult group of patients is venlafaxine - a selective serotonin-noradrenaline reuptake inhibitor. It has no significant adverse effects on the cardiovascular system and does not affect the electrocardiographic image [36]. In large doses, it can raise blood pressure and the heart rate. Unlike SSRI, it does not inhibit cytochrome P450 and tends not to bind with plasma proteins [36].

Tricyclic antidepressants (TCA) are contraindicated in patients with HF and depression. They cause lowering of blood pressure, tachycardia and conduction disorders related to sodium channel block. They prolong atrial and ventricular depolarization time as well as prolonging the QT, PR and QRS intervals. As a result of QT interval prolongation and norepinephrine uptake inhibition, they may have a pro-arrhythmic action. In $20 \%$ of patients, they cause orthostatic hypotonia; this is of particular importance in elderly patients with a tendency toward cerebral hypoperfusion. TCA lower myocardial contractility [36]. The results of the CAST trial show that TCA should be avoided in patients with cardiovascular diseases due to the risk of lifethreatening arrhythmias, and particularly in patients who receive other medication that prolongs the QT interval [37].

Some authors believe behavioural therapy to be more effective than pharmacotherapy in the treatment of recurrent depression [38]. Kostis et al. showed that non-pharmacological treatment of depression improves physical fitness and emotional condition of patients with CHF [39]. The recently published SEARCH trial (Support, Education, and Research in Chronic Heart Failure) [40] showed that an 8-week mindfulness-based psycho-educational intervention led to significantly better symptoms of CHF at 12 months in patients with $\mathrm{HF}$ and depression. Despite the recognized association between depression and negative outcome in HF patients, it is still unclear whether pharmacological or behavioural treatment of depression may enhance the outcome [41].

\section{Conclusions}

In the light of current knowledge, the detection of depressive symptoms and the efficacy of depression treatment in HF patients seem inadequate. This may be due to a number of factors. Firstly, diagnosing depression may be challenging as the two diseases have a similar clinical picture, including apathy, tiredness and anergy. Secondly, there are no standards for the management of patients with HF and concomitant depression. The diagnostic process is further complicated by masked depression, i.e. depression where all primary and secondary symptoms are only slight, and the main clinical picture is not depression but sleep disorders, headaches, chronic anxiety and compulsion. Patients with masked depression rarely visit a psychiatrist and usually seek help from doctors of other specialties, who in turn struggle to see depression as the primary cause of the patient's ailments. What is more, these patients rarely undergo effective depression therapy for the appropriate amount of time. Hence, it is necessary to carry out screening tests for depression in all HF patients and to establish standards of management in HF patients with concomitant depression.

\section{Acknowledgements}

The authors wish to thank Sandra K. Lindon for linguistic assistance in the preparation of this manuscript.

\section{Literature}

1. McMurray JJ, Adamopoulos S, Anker SD, Auricchio A, Böhm M, Dickstein K, Falk V, Filippatos G, Fonseca C, Gomez-Sanchez MA, Jaarsma T, Køber L, Lip GY, Maggioni AP, Parkhomenko A, Pieske BM, Popescu BA, Rønnevik PK, Rutten FH, Schwitter J, Seferovic P, Stepinska J, Trindade PT, Voors AA, Zannad F, Zeiher A; ESC Committee for Practice Guidelines. ESC Guidelines for the diagnosis and treatment of acute and chronic heart failure 2012: The Task Force for the Diagnosis and Treatment of Acute and Chronic Heart Failure 2012 of the European Society of Cardiology. Developed in collaboration with the Heart Failure Association (HFA) of the ESC. Eur Heart J 2012; 33; 1787-1847.

2. Jaarsma T, Haaijer-Ruskamp FM, Sturm H, Van Veldhuisen DJ. Management of heart failure in The Netherlands. Eur J Heart Fail 2005; 7: 371-375.

3. Ho KK, Pinsky JL, Kannel WB, Levy D. The epidemiology of heart failure: the Framingham Study. J Am Coll Cardiol 1993; 22: 6A-13A.

4. Bleumink GS, Knetsch AM, Sturkenboom MC, Straus SM, Hofman A, Deckers JW, Witteman JC, Stricker BH. Quantifying the heart failure epidemic: prevalence, incidence rate, lifetime risk and prognosis of heart failure. The Rotterdam Study. Eur Heart J 2004; 25: 1614-1619.

5. Krishnan KR, Delong M, Kraemer H, Carney R, Spiegel D, Gordon C, McDonald W, Dew M, Alexopoulos G, Buckwalter K, Cohen PD, Evans D, Kaufmann PG, Olin J, Otey E, Wainscott C. Comorbidity of depression with other medical diseases in the elderly. Biol Psychiatry 2002; 52: 559-588.

6. Nicholson A, Kuper H, Hemingway H. Depression as an aetiologic and prognostic factor in coronary heart disease: a meta-analysis of 6362 events among 146583 participants in 54 observational studies. Eur Heart J 2006; 27: $2763-2774$.

7. Klasyfikacja zaburzeń psychicznych i zaburzeń zachowania w ICD-10. Badawcze kryteria diagnostyczne. Uniwersyteckie Wydawnictwo Medyczne Vesalius, Instytut Psychiatrii i Neurologii. Kraków - Warszawa 1998.

8. American Psychiatric Association: Diagnostic and Statistical Manual of Mental Disorders 4th ed. text revision. American Psychiatric Association, Washington DC 2000.

9. Cierpiałowska L. Psychopatologia. Wykłady z psychologii. Wydawnictwo Naukowe Scholar 2009; 240-270.

10. Ressler KJ, Nemeroff CB. Role of serotonergic and noradrenergic systems in the pathophysiology of depression and anxiety disorders. Depress Anxiety 2000; 12: 2-19.

11. Dunlop BW, Nemeroff CB. The role of dopamine in the pathophysiology of depression. Arch Gen Psychiatry 2007; 64: 327-337.

12. Duman RS. Pathophysiology of depression: the concept of synaptic plasticity. Eur Psych 2002; 17: 306-310.

13. Rutledge T, Reis VA, Linke SE, Greenberg BH, Mills PJ. Depression in heart failure. A meta-analytic review of prevalence, intervention effects and associations with clinical outcomes. Am Coll Cardiol 2006; 48: 1527-1537. 
14. Parissis JT, Fountoulaki K, Paraskevaidis J, Kremastinos D. Depression in chronic heart failure: novel pathophysiological mechanisms and therapeutic approaches. Expert Opin Investig Drugs 2005; 14: 567-577.

15. Ehlert U, Gaab J, Heinrichs M. Psychoneuroendocrinological contributions to the etiology of depression, posttraumatic stress disorder, and stress-related bodily disorders: the role of the hypothalamus-pituitary-adrenal axis. Biol Psychol 2001; 57: 141-152.

16. Nahshoni E, Aizenberg D, Strasberg B, Dorfman P, Sigler M, Imbar S, Weizman A. QT dispersion in the surface electrocardiogram in elderly patients with major depression. J Affect Disord 2000; 60: 197-200.

17. Mann DL. Inflammatory mediators and the failing heart: past, present and the foreseeable future. Circ Res 2002; 91: 988-998.

18. van Melle JP, de Jonge P, Ormel J, Crijns HJ, van Veldhuisen DJ, Honig A, Schene AH, van den Berg MP; MIND-IT investigators. Relationship between left ventricular dysfunction and depression following myocardial infarction: data from the MIND-IT. Eur Heart J 2005; 26: 2650-2656.

19. Gottlieb SS, Kop WJ, Ellis SJ, Binkley P, Howlett J, O'Connor C, Blumenthal JA, Fletcher G, Swank AM, Cooper L; HF-ACTION Investigators. Relation of depression to severity of illness In heart failure (from Heart Failure And a Controlled Trial Investigating Outcomes of Exercise Training [HF-ACTION]. Am J Cardiol 2009; 103: 1285-1289.

20. Faris R, Purcell H, Henein MY, Coats AJ. Clinical depression is common and significantly associated with reduced survival In patients with non-ischemic heart failure. Eur J Heart Fail 2002; 4: 541-551.

21. Lesman-Leegte I, van Veldhuisen DJ, Hillege HL, Moser D, Sanderman R, Jaarsma T. Depressive symptoms and outcomes in patients with heart failure: data from the COACH study. Eur J Heart Fail 2009; 11: 1202-1207.

22. van den Broek KC, Defilippi CR, Christenson RH, Seliger SL, Gottdiener JS, Kop WJ. Predictive value of depressive symptoms and B-type natriuretic peptide for new-onset heart failure and mortality. Am J Cardiol 2011; 107: 723-729.

23. Albert NM, Fonarow GC, Abraham WT, Gheorghiade M, Greenberg BH, Nunez E, O'Connor CM, Stough WG, Yancy CW, Young JB. Depression and clinical outcomes In heart failure: an OPTIMIZE-HF analysis. Am J Med 2009; 122: 366-373.

24. Tousoulis D, Antoniades C, Drolias A, Stefanadi E, Marinou K, Vasiliadou C, Tsioufis C, Toutouzas K, Latsios G, Stefanadis C. Selective serotonin reuptake inhibitors modify the effect of beta-blockers on long-term survival of patients with end-stage heart failure and major depression. J Card Fail 2008; 14: 456-464.

25. Johansson P, Lesman-Leegte I, Svensson E, Voors A, van Veldhuisen DJ, Jaarsma T. Depressive symptoms and inflammation In patients hospitalized for heart failure. Am Heart J 2011; 161: 1053-1059.

26. Parissis JT, Adamopoulos S, Rigas A, Kostakis G, Karatzas D, Venetsanou K, Kremastinos DT. Comparison of circulating proinflammatory cytokines and soluble apoptosis mediators in patients with chronic heart failure with versus without symptoms of depression. Am J Cardiol 2004; 94: 1326-1328.

27. Moorman AJ, Mozaffarian D, Wilkinson CW, Lawler RL, McDonald GB, Crane BA, Spertus JA, Russo JE, Stempien-Otero AS, Sullivan MD, Levy WC. In patients with heart failure elevated soluble TNF-receptor 1 is associated with higher risk of depression. J Card Fail 2007; 13: 738-743.

28. Anand IS, Latini R, Florea VG, Kuskowski MA, Rector T, Masson S, Signorini S, Mocarelli P, Hester A, Glazer R, Cohn JN; Val-HeFT Investigators. C-reactive protein In heart failure. Prognostic value and effect of valsartan. Circulation 2005; 112: 1428-1434.
29. Xue C, Feng Y, Wo J, Li Y. Prognostic value of high-sensitivity C-reactive protein in patients with chronic heart failure. N Z Med J 2006: 119: U23314.

30. Lamblin N, Mouquet F, Hennache B, Dagorn J, Susen S, Bauters C, de Groote P. High-sensitivity $C$-reactive protein: potential adjunct for risk stratification in patients with stable congestive heart failure. Eur Heart J 2005; 26: 2245-2250.

31. Kaneko K, Kanda T, Yamauchi Y, Hasegawa A, Iwasaki T, Arai M, Suzuki T, Kobayashi I, Nagai R. C-reactive protein in dilated cardiomyopathy. Cardiology 1999; 9: 215-219.

32. Ronnow BS, Reyna SP, Muhlestein JB, Horne BD, Allen Maycock CA, Bair TL, Carlquist JF, Kfoury AG, Anderson JL, Renlund DG; International Heart Collaborative Study Group. C-reactive protein predicts death in patients with non-ischemic cardiomyopathy. Cardiology 2005; 104: 196-201.

33. Gottlieb SS, Kop WJ, Thomas SA, Katzen S, Vesely MR, Greenberg N, Marshall J, Cines M, Minshall S. A double-blind placebo controlled pilot study of controlled release paroxetine on depression and quality of life in chronic heart failure. Am Heart J 2007; 153: 868-873.

34. Jiang W, O'Connor C, Silva SG, Kuchibhatla M, Cuffe MS, Callwood DD, Zakhary B, Henke E, Arias RM, Krishnan R; SADHART-CHF Investigators. Safety and Efficacy of Sertraline for Depression in Patients with CHF (SADHART-CHF): A randomized, double-blind, placebo-controlled trial of sertraline for major depression with congestive heart failure. Am Heart J 2008; 156: 437-444.

35. van Zyl LT, Lespérance F, Frasure-Smith N, Malinin Al, Atar D, Laliberté MA, Serebruany VL. Platelet and endothelial activity in comorbid major depression and coronary artery disease patients treated with citalopram: the Canadian Cardiac Randomized Evaluation of Antidepressant and Psychotherapy Efficacy Trial (CREATE) biomarker sub-study. J Thromb Thrombolysis 2009; 27: 48-56.

36. Mutschler. Farmakologia i toksykologia. Urban \& Partner, Wrocław 2004; 177-180.

37. Roose SP, Glassmann AH. Antidepressant choice in patients with cardiac disease: lessons from the Cardiac Arrhythmia Suppression Trial (CAST) studies. J Clin Psychiatry 1994; 55: 98-100, suppl A: 87-87.

38. O-Hea E, Houseman J, Bedek K, Sposato R. The use of cognitive behavioral therapy In the treatment of depression for individuals with CHF. Heart Fail Rev 2009; 14: 13-20.

39. Kostis JB, Rosen RC, Cosgrove NM, Shindler DM, Wilson AC. Nonpharmacologic therapy improves functional and emotional status in congestive heart failure. Chest 1994; 106: 996-1001.

40. Sullivan MJ, Wood L, Terry J, Brantley J, Charles A, McGee V, Johnson D, Krucoff MW, Rosenberg B, Bosworth HB, Adams K, Cuffe MS. The Support, Education, and Research in Chronic Heart Failure Study (SEARCH): a mindfulness-based psychoeducational intervention improves depression and clinical symptoms in patients with chronic heart failure. Am Heart J 2009; 289: 3106-3116.

41. O'Connor CM, Jiang W, Kuchibhatla M, Mehta RH, Clary GL, Cuffe MS, Christopher EJ, Alexander JD, Califf RM, Krishnan RR. Antidepressant use, depression, and survival in patients with heart failure. Arch Intern Med. 2008; 168: 2232-2237. 